\title{
Analisis Kualitas Bakteriologis (MPN E-Coli) Depot Air Minum Isi Ulang di Kecamatan Johar Baru
}

\author{
Meiana Harfika, Afnan Hanifah \\ Fakultas Ilmu Kesehatan Universitas Respati Indonesia \\ meianaharfika@urindo.ac.id
}

\begin{abstract}
Abstrak
Setiap manusia membutuhkan air untuk kelangsungan hidupnya. Dewasa ini kebutuhan air minum makin banyak apalagi dikota - kota yang padat penduduk seperti kota Jakarta. Padatnya penduduk dan berkurangnya lahan yang ada di Jakarta menyebabkan masyarakat beralih ke air minum isi ulang yang harganya relatif murah dan mudah didapat dilingkungan sekitar. Depot air minum harus diawasi secara berkala untuk memastikan air minum yang layak konsumsi. Tujuan penelitian yaitu untuk mengetahui faktor yang berhubungan dengan terkontaminasinya bakteri E.coli pada depot air minum isi ulang. Desain penelitian yang digunakan adalah cross sectional. Populasi yang digunakan adalah semua depot air minum isi ulang di kecamatan Johar Baru berjumlah 29 depot. Data dikumpulkan secara primer dan sekunder menggunakan kuesioner, wawancara, observasi dan pengecekan dokumen di Puskesmas. Hasil yang didapatkan yaitu terdapat korelasi antara masa pemakaian lampu UV dengan kualitas bakteriologis ( $p$ value = 0,001 ) dengan nilai $O R=2,250$. Ada hubungan antara pengetahuan pemilik pada pemeliharaan peralatan dengan kualitas bakteriologis $(p$ value $=0,044$ ) dengan nilai $O R=3,125$. Kemudian terdapat korelasi antara kelengkapan administrasi dengan kualitas bakteriologis ( $p$ value $=0,001$ ) dengan nilai $O R=4,400$. Diharapkan bagi pemilik depot air minum isi ulang agar tetap memeriksa air yang akan dijual ke masyarakat dan meningkatkan pengetahuan mengenai pemeliharaan depot, serta berkoordinasi dengan puskesmas terkait.
\end{abstract}

Kata kunci : Depot air minum isi ulang, Bakteri E. Coli, Air Minum.

\section{Abstract}

Every human needs some water for survival. Nowadays, the need for drinking water are is increasing, Moreover in a city with densenly population such as Jakarta. Dense population and the reduced land in Jakarta might caused people turn to refilled drinking water which is relatively cheap and easy to obtain in the surrounding environment. Drinking water depots must be monitored regularly to ensure drinking water is fit for consumption. The purpose of the study was to determine the factors associated with the contamination of E.coli bacteria in refill drinking water depots. The research design used was cross sectional. What people used is all refill drinking water depots in Johar Baru sub-district totaling 29 depots. Data were collected primary and secondary using questionnaires, interviews, observation and document checking at the Health Community Center. The results obtained are that there is a relationship between the use of UV lamps with bacteriological quality ( $p$ value $=0.001$ ) with an $O R$ value $=2,250$. There is a relationship between the owner's knowledge on equipment maintenance and bacteriological quality ( $p$ value $=0.044$ ) with an $\mathrm{OR}$ value of 3.125 . There is a relationship between administrative completeness and bacteriological quality ( $p$ value $=0.001$ ) with $O R$ value $=4.400$. Expected that the owner of the refillable water storehouse will continue to check the water that will be sold to the community and increase and increase knowledge about depot maintenance, and coordination with community health center.

http://ejournal.urindo.ac.id/index.php/jukmas 
Keywords : Refillable water storehouse, e.coli bacteria, drinking water

\section{PENDAHULUAN}

$$
\begin{aligned}
& \text { Salah satu usaha untuk } \\
& \text { meningkatkan derajat kesehatan yang } \\
& \text { setinggi-tingginya dalam perilakuhidup bersih } \\
& \text { dan sehat (PHBS) adalah Sanitasi Total } \\
& \text { Berbasis Masyarakat (STBM) karena dengan } \\
& \text { perilaku hidup bersih dan sehat dapat } \\
& \text { menghindari penyebaran penyakit berbasis } \\
& \text { lingkungan, kemampuan masyarakat agar } \\
& \text { ditingkatkan, serta tingkatkan akses air minum } \\
& \text { dan sanitasi dasar. STBM merupakan suatu } \\
& \text { pendekatan guna mengubah perilaku higienis }
\end{aligned}
$$
dan saniter melalui pemberdayaan masyarakat dengan metode pemicuan. Salah satu pilar dalam STBM yaitu Pengelolaan Air Minum serta pengelolaan Makanan Rumah Tangga dengan cara melakukan suatu kegiatan mengelola air minum dan makanan di rumah tangga dengan tujuan memperbaiki dan menjaga kualitas air dari sumber air yang akan digunakan untuk air minum, serta untuk menerapkan prinsip higiene sanitasi pangan dalam proses pengelolaan makanan di rumah tangga. (1)

Setiap individu membutuhkan air untuk kelangsungan hidupnya, begitu juga air untuk di konsumsi atau air minum. Kebutuhan air minum pada orang dewasa agar tidak kekurangan cairan yaitu sekitar 8 gelas berukuran $230 \mathrm{ml}$ per hari atau jika di total menjadi 2 liter air putih perhari. Maka dari itu air wajib mempunyai syarat khusus supaya air tersebut tidak menimbulkan penyakit bagi manusia

Sumber air minum yang dimanfaatkan dalam rumah tangga guna air minum bersumber dari sumur gali terlindung $(24,7 \%)$, air ledeng $(14,2 \%)$, sumur bor atau pompa $(14,0 \%)$ dan air dari depot air minum $(13,8 \%)$. Hasil Riskesdas tersebut adalah bukti terdapat peningkatan dalam penggunaan air minum isi ulang pada rumah tangga dari 13,8\% pada tahun 2010 meningkat menjadi $21 \%$ pada tahun 2013 (2)

Pertumbuhan penduduk yang terus bertambah atau meningkat dari tahun ke tahun menjadikan kebutuhan masyarakat akan air minum pun ikut meningkat, akan tetapi tidak diimbangi dengan ketersediaan air bersih yang ada terutama di daerah-daerah padat penduduk seperti DKI Jakarta. Padatnya tempat tinggal di jakarta dan kurangnya lahan yang tersedia serta minimnya rumah yang belum memiliki septictank membuat air tanah mengalami pencemaran yang sangat besar. Sehingga air tanah tidak lagi nyaman untuk dijadikan bahan baku air minum sehingga air minum isi ulang merupakan salah satu jawaban pemenuhan kebutuhan air minum pada penduduk Indonesia yang murah, praktis dan instan. Sehingga hal tersebut menjadi alasan mengapa warga masyarakat memilah 
air minum isi ulang untuk dikonsumsi di Rumah Tangga (3)

Air minum isi ulang dapat dikatakan menjadi favorit bagi masyarakat yang ketersediaan air tanah atau air PDAM yang tidak memadai. Hal tersebut menjadikan Depot air minum makin banyak di beberapa wilayah. Depot air minum merupakan suatu usaha yang melakukan proses mengolah air baku menjadi air yang siap diminum serta menjual langsung kepada pembeli. Depot air minum isi ulang wajib memenuhi persyaratan air minum yang dihasilkan memenuhi standar baku mutu atau persyaratan kualitas air minum sesuai dengan peraturan perundangundangan serta persyaratan hygiene sanitasi dalam mengolah atau pengolahan air minum.

\section{METODE}

Metode yang digunakan dalam penelitian yaitu metode pendekatan kuantitatif dengan desain studi cross sectional. Dalam hal ini peneliti ingin mengetahui analisis yang berhubungan dengan variabelvariabel pemeliharaan peralatan dan pengawasan depot air minum isi ulang terhadap kualitas bakteriologis (Escherichia Coli) di wilayah Kecamatan Johar Baru Tahun 2020. Populasi dalam penelitian ini adalah 31 Depot Air Minum Isi Ulang (DAMIU) yang tercatat di Puskesmas Kecamatan Johar Baru dan 29 pengelola depot air minum isi ulang yang berada di Kecamatan Johar Baru, Jakarta Pusat. Teknik sampel yang dilakukan dalam penelitian ini menggunakan Total Sampling. Pemilihan sampel didasarkan atas kriteriakriteria tertentu yang mempunyai keterkaitan berdasarkan tujuan penelitian. Maka sampel yang diambil sebanyak 29 DAMIU yang sudah diperiksakan kualitas air minumnya oleh Puskesmas. Pengumpulan data yang digunakan adalah dengan metode wawancara, observasi, bukti dokumen serta kuesioner. Data dikumpulkan yaitu data primer dan data sekunder, data primer dikumpulkan secara observasi (pengamatan) di lokasi dan wawancara (interview) yang dilakukan kepada pengelola atau yang melayani penjualan depot air minum isi ulang. Sedangkan data sekunder merupakan data depot air minum isi ulang yang telah dilakukan pemeriksaan bakteriologis oleh Puskesmas Kecamatan Johar Baru Tahun 2020 dan hasil pemeriksaan bakteriologis air minum isi ulang yang sudah dilakukan pemeriksaan bakteriologis oleh Puskesmas Kecamatan Johar Baru Tahun 2019

\section{HASIL DAN PEMBAHASAN}

Tabel 1.1 Data univariat

\begin{tabular}{|c|c|c|c|}
\hline $\begin{array}{l}\mathrm{N} \\
\mathrm{O}\end{array}$ & $\begin{array}{l}\text { Variabel } \\
\text { penelitian }\end{array}$ & $\begin{array}{c}\text { Jumla } \\
\mathrm{h}\end{array}$ & $\begin{array}{c}\text { Persentas } \\
\text { e (\%) }\end{array}$ \\
\hline \multirow[t]{8}{*}{1} & Kualitas & & \\
\hline & Bakteriologis & & \\
\hline & (MPN E.Coli) & 12 & $41,4 \%$ \\
\hline & - Terkontaminas & 17 & $58,6 \%$ \\
\hline & $\mathrm{i}$ & & \\
\hline & - Tidak & & \\
\hline & Terkontaminas & & \\
\hline & i & & \\
\hline \multirow[t]{2}{*}{2} & Masa Pemakaian & & \\
\hline & Lampu UV & & \\
\hline
\end{tabular}




\begin{tabular}{|c|c|c|c|}
\hline & $\begin{array}{ll}\text { - } & \text { Tidak baik } \\
\text { - } & \text { Baik }\end{array}$ & $\begin{array}{c}8 \\
21 \\
\end{array}$ & $\begin{array}{c}27,6 \% \\
72,4\end{array}$ \\
\hline 3 & $\begin{array}{l}\text { Pengetahuan } \\
\text { Pemilik } \\
\text { - } \quad \text { Kurang baik } \\
\text { - } \quad \text { Baik }\end{array}$ & $\begin{array}{c}4 \\
25\end{array}$ & $\begin{array}{l}13,8 \% \\
86,2 \%\end{array}$ \\
\hline 4 & $\begin{array}{l}\text { Kelengkapan } \\
\text { Administrasi } \\
\text { - } \quad \text { Tidak } \\
\text { memenuhi } \\
\text { syarat } \\
\text { - } \text { Memenuhi } \\
\text { syarat }\end{array}$ & 25 & $\begin{array}{l}24,1 \% \\
75,9 \%\end{array}$ \\
\hline & & 29 & $100 \%$ \\
\hline
\end{tabular}

Berdasarkan tabel 1.1 diketahui bahwa dari total Depot Air Minum Isi Ulang sebanyak 29 DAMIU, Depot Air Minum Isi Ulang dengan hasil E.Coli $\geq 0$ yaitu sebanyak 17 DAMIU (59\%), sedangkan depot air minum terkontaminasi E.Coli > 0 yaitu sebanyak 12 DAMIU (41\%). Distribusi frekuensi masa pemakaian lampu UV depot air minum di
Wilayah Kecamatan Johar Baru, Jakarta Pusat Tahun 2020 yaitu sebanyak 8 depot $(27,6 \%)$ yang tidak baik sedangkan depot air minum isi ulang yang baik sebanyak 21 depot $(72,4 \%)$. Distribusi frekuensi pengetahuan pemilik depot air minum di Wilayah Kecamatan Johar Baru, Jakarta Pusat Tahun 2020 yaitu sebanyak 4 depot $(13,8 \%)$ yang berpengetahuan kurang sedangkan depot air minum isi ulang yang berpengetahuan tinggi sebanyak 25 depot (86,2\%). Distribusi frekuensi kelengkapan administrasi depot air minum di Wilayah Kecamatan Johar Baru, Jakarta Pusat Tahun 2020 yaitu sebanyak 7 depot $(24,1 \%)$ yang tidak memenuhi syarat sedangkan depot air minum isi ulang yang memenuhi syarat sebanyak 22 depot $(75,9 \%)$.

Tabel 1.2 Hubungan Antara Masa Pemakaian Lampu UV dengan Kualitas Bakteriologis (MPN E.Coli)

\begin{tabular}{|c|c|c|c|c|c|c|c|c|c|}
\hline \multirow{3}{*}{ No } & \multirow{3}{*}{$\begin{array}{c}\text { Masa } \\
\text { Pemakaian } \\
\text { Lampu UV }\end{array}$} & \multicolumn{4}{|c|}{ Kualitas Bakteriologis } & & & \multirow{3}{*}{$\begin{array}{c}P \\
\text { Value }\end{array}$} & \multirow{3}{*}{ OR } \\
\hline & & \multicolumn{2}{|c|}{ Terkontaminasi } & \multicolumn{2}{|c|}{$\begin{array}{c}\text { Tidak } \\
\text { Terkontaminasi }\end{array}$} & \multicolumn{2}{|c|}{ Total } & & \\
\hline & & $\mathrm{n}$ & $\%$ & $\mathrm{n}$ & $\%$ & $\mathrm{~N}$ & $\%$ & & \\
\hline 1. & Tidak Baik & 8 & 100 & 0 & 0 & 8 & 100 & \multirow{3}{*}{0,000} & 5,250 \\
\hline 2. & Baik & 4 & 19,0 & 17 & 81,0 & 21 & 100 & & $(2,174-$ \\
\hline & Jumlah & 12 & 41,4 & 17 & 58,6 & 29 & 100 & & $12,679)$ \\
\hline
\end{tabular}

Berdasarkan tabel 1.2 diketahui bahwa depot air minum isi ulang yang memiliki masa pemakaian lampu UV tidak baik pada kualitas bakteriologis terkontaminasi sebanyak 8 depot (100\%) dan tidak ada depot air minum isi ulang yang memiliki masa pemakaian lampu UV tidak baik pada kualitas bakteriologis depot air minum isi ulang tidak terkontaminasi, sedangkan depot air minum isi ulang yang memiliki masa pemakaian lampu UV baikpada kualitas bakteriologis depot air minum isi ulang terkontaminasi sebanyak 4 depot $(19,0 \%)$ dan depot air minum isi ulang yang memiliki masa pemakaian lampu UV baik pada kualitas bakteriologis depot air minum isi ulang tidak terkontaminasi sebanyak 17 depot $(81,0 \%)$ 
Berdasarkan hasil uji statistik hubungan masa pemakaian lampu UV dengan kualitas bakteriologis didapatkan nilai $p$-value sebesar $0,000 \leq \alpha(0,05)$ maka Ho ditolak, yang berarti ada pengaruh yang bermakna antara masa pemakaian lampu UV dengan kualitas bakteriologis di Wilayah Kecamatan Johar
Baru, Jakarta Pusat Tahun 2020. Nilai OR $=$ 5,520 artinya depot air minum isi ulang yang memiliki masa pemakaian lampu UV tidak baik memiliki risiko 5,520 kali lebih besar kualitas bakteriologisnya terkontaminasi dibandingkan depot air minum isi ulang yang masa pemakaian lampu UV baik.

Tabel 1.3 Hubungan Antara Pengetahuan Pemilik Pada Pemeliharaan Peralatan dengan Kualitas Bakteriologis (MPN E.Coli)

\begin{tabular}{|c|c|c|c|c|c|c|c|c|c|}
\hline \multirow{3}{*}{ No. } & \multirow{3}{*}{$\begin{array}{c}\text { Pengetahua } \\
\text { n Pemilik }\end{array}$} & \multicolumn{4}{|c|}{ Kualitas Bakteriologis } & & & \multirow{3}{*}{$\begin{array}{c}\mathbf{P} \\
\text { Value }\end{array}$} & \multirow{3}{*}{ OR } \\
\hline & & \multicolumn{2}{|c|}{$\begin{array}{l}\text { Terkontamin } \\
\text { asi }\end{array}$} & \multicolumn{2}{|c|}{$\begin{array}{c}\text { Tidak } \\
\text { Terkontamina } \\
\mathrm{s} \\
\end{array}$} & \multicolumn{2}{|c|}{ Total } & & \\
\hline & & $\mathrm{n}$ & $\%$ & $\mathrm{n}$ & $\%$ & $\mathrm{~N}$ & $\%$ & & \\
\hline 1. & Kurang & 4 & 100 & 0 & 0 & 4 & 100 & & 3,125 \\
\hline 2. & Tinggi & 8 & 32,0 & 17 & 68,0 & 17 & 100 & 0,044 & $(1,765$ \\
\hline & Jumlah & 12 & 41,4 & 17 & 58,6 & 29 & 100 & & $\begin{array}{c}- \\
5,534)\end{array}$ \\
\hline
\end{tabular}

Berdasarkan tabel 1.4 diketahui bahwa depot air minum isi ulang yang memiliki pengetahuan kurang pada kualitas bakteriologis terkontaminasi sebanyak 4 depot $(100 \%)$ dan tidak ada depot air minum isi ulang yang memiliki pengetahuan kurang pada kualitas bakteriologis depot air minum isi ulang tidak terkontaminasi, sedangkan depot air minum isi ulang yang memiliki pengetahuan tinggi pada kualitas bakteriologis depot air minum isi ulang terkontaminasi sebanyak 8 depot $(32,0 \%)$ dan depot air minum isi ulang yang memiliki pengetahuan tinggipada kualitas bakteriologis depot air minum isi ulang tidak terkontaminasi sebanyak 17 depot (68,0\%)

Berdasarkan hasil uji statistik hubungan pengetahuan dengan kualitas bakteriologis didapatkan nilai $p$-value sebesar $0,044 \leq \alpha$ $(0,05)$ maka Ho ditolak, yang berarti ada pengaruh yang bermakna antara pengetahuan dengan kualitas bakteriologis di Wilayah Kecamatan Johar Baru, Jakarta Pusat Tahun 2020. Nilai $O R=3,125$ artinya depot air minum isi ulang yang memiliki pengetahuan kurang memiliki risiko 3,125 kali lebih besar kualitas bakteriologisnya terkontaminasi dibandingkan depot air minum isi ulang yang pengetahuan baik 
Tabel 1.4 Hubungan Antara Kelengkapan Administrasi dengan Kualitas Bakteriologis (MPN E.Coli)

\begin{tabular}{|c|c|c|c|c|c|c|c|c|c|}
\hline \multirow{3}{*}{ No. } & \multirow{3}{*}{$\begin{array}{l}\text { Kelengkapan } \\
\text { Administrasi }\end{array}$} & \multicolumn{4}{|c|}{ Kualitas Bakteriologis } & & & \multirow{3}{*}{$\begin{array}{c}\mathbf{P} \\
\text { Value }\end{array}$} & \multirow{3}{*}{ OR } \\
\hline & & \multicolumn{2}{|c|}{$\begin{array}{l}\text { Terkontamin } \\
\text { asi }\end{array}$} & \multicolumn{2}{|c|}{$\begin{array}{c}\text { Tidak } \\
\text { Terkontamin } \\
\text { asi }\end{array}$} & \multicolumn{2}{|c|}{ Total } & & \\
\hline & & $\mathrm{n}$ & $\%$ & $\mathrm{n}$ & $\%$ & $\mathrm{~N}$ & $\%$ & & \\
\hline 1. & $\begin{array}{l}\text { Tidak Memenuhi } \\
\text { Syarat }\end{array}$ & 7 & 100 & 0 & 0 & 7 & 100 & & $\begin{array}{l}4,400 \\
(2,036\end{array}$ \\
\hline 2. & Memenuhi Syarat & 5 & 22,7 & 17 & 77,3 & 22 & 100 & 0,001 & - \\
\hline & Jumlah & 12 & 41,4 & 17 & 58,6 & 29 & 100 & & $9,508)$ \\
\hline
\end{tabular}

Berdasarkan tabel diatas diketahui bahwa depot air minum isi ulang yang memiliki kelengkapan administrasi tidak memenuhi syarat pada kualitas bakteriologis terkontaminasi sebanyak 7 depot (100\%) dan tidak ada depot air minum isi ulang yang memiliki kelengkapan administrasi tidak memenuhi syarat pada kualitas bakteriologis tidak terkontaminasi, sedangkan depot air minum isi ulang yang memiliki kelengkapan administrasi memenuhi syarat pada kualitas bakteriologis terkontaminasi sebanyak 5 depot $(22,7 \%)$ dan depot air minum isi ulang yang memiliki kelengkapan administrasi memenuhi syarat pada kualitas bakteriologis tidak terkontaminasi sebanyak 17 depot (77,3\%)

Berdasarkan hasil uji statistik hubungan kelengkapan administrasi dengan kualitas bakteriologis didapatkan nilai $p$-value sebesar $0,001 \leq \alpha(0,05)$ maka Ho ditolak, yang berarti ada pengaruh yang bermakna antara kelengkapan administrasi dengan kualitas bakteriologis di Wilayah Kecamatan Johar Baru, Jakarta Pusat Tahun 2020. Nilai OR = 4,400 artinya depot air minum isi ulang yang memiliki kelengkapan administrasi tidak memenuhi syarat memiliki risiko 4,400 kali lebih besar kualitas bakteriologisnya terkontaminasi dibandingkan depot air minum isi ulang yang kelengkapan administrasi memenuhi syarat.

\section{PEMBAHASAN}

Hubungan Masa Pemakaian Lampu Ultraviolet DAMIU Dengan Kualitas Bakteriologis (MPN E.Coli). Berdasarkan penelitian yang sudah dilakukan dapat dilihat bahwa pada masa pemakaian lampu UV DAMIU yang tidak baik terhadap kontaminasi bakteriologis (MPN E.Coli) terkontaminasi sebanyak 8 DAMIU (100\%) dan pada masa pemakaian lampu UV DAMIU yang baik terhadap kontaminasi bakteriologis (MPN E.Coli) yang tidak terkontaminasi sebanyak 17 DAMIU (81\%). Melalui proses pengolahan data terdapat hubungan yang bermakna antara masa pemakaian lampu UV DAMIU dengan Kontaminasi Bakteriologis di Wilayah Kecamatan Johar Baru Jakarta Pusat. Adapun nilai Odds Ratio (OR) yang didapatkan yaitu = 5,520 berarti masa pemakaian lampu UV DAMIU yang bidak baik memiliki peluang atau kesempatan untuk terkontaminasi 
Bakteriologis (MPN E.Coli) 5,520 kali lebih besar dibandingkan baik dan tidak Terkontaminasi Bakteriologis (MPN E.Coli)

Menurut Kepmenperindag No. 651 Tahun 2004 mengenai syarat teknis depot air minum dan perdagangan, menyebutkan bahwa Desinfektan berfungsi sebagai pembunuh kuman patogen. Beberapa Alat desinfektan yang dapat digunakan untuk mendesinfeksi air minum yaitu ozonisasi atau Ultraviolet dengan panjang gelombang $254 \mathrm{~nm}$ atau $2537^{\circ} \mathrm{A}(4)$

Hasil penelitian ini mengacu kepada (5) disimpulkan bahwa terdapat 4 DAMIU (13.3\%) yang mempunyai waktu pemakaian lampu UV yang kurang baik yaitu lebih dari 36 bulan atau lebih dari 3 tahun dan 26 DAMIU $(86,7 \%)$ dengan waktu pakai lampu UV baik yaitu kurang dari 36 bulan atau kurang dari 3 tahun.

Selanjutnya yaitu hubungan masa pemakaian lampu ultraviolet dengan kualitas bakteriologis masih didapatkan hasil 4 (19,0\%) DAMIU yang memenuhi syarat namun terkontaminasi. Menurut penulis hal ini mungkin terjadi disebabkan karena panjang gelombang yang dihasilkan oleh lampu UV tergolong rendah sehingga kemampuan lampu sinar UV dalam melenyapkan segala macam bakteri akan jauh berkurang, rendahnya panjang gelombang yang dihasilkan salah satunya dikarenakan produksi air minum pada DAMIU perharinya melebihi rata-rata namun perlu diadakannya penelitian lebih lanjut.
Dari hasil wawancara dan observasi juga diperoleh bahwa masih ada lampu UV pada DAMIU yang di pakai melebihi 36 bulan atau lebih dari 3 tahun dan juga terdapat satu depot air minum isi ulang yang lampu UVnya tidak berfungsi selama 1 tahun berturut-turut. Pemilik kurang memperhatikan masa pemakaian atau spesifikasi dari lampu ultraviolet bahwa lampu ultraviolet memiliki masa pakai, pemilik cenderung mengganti hanya jika lampunya sudah benar-benar mati saja sehingga jika lampu UV masih menyala dianggap bahwa lampu tersebut masih berfungsi, pemilik depot juga kesulitan untuk melakukan pemeliharaan peralatan dikarenakan supplier pemasok peralatan air minum isi ulang sulit untuk di hubungi, hal ini yang dapat menyebabkan bakteri yang terdapat dalam air belum hilang sepenuhnya.

Hubungan Pengetahuan Pemilik Pada Pemeliharaan Peralatan Depot Air Minum Isi Ulang Dengan Kualitas Bakteriologis (MPN E.Coli)

Hasil penelitian yang sudah selesai dilakukan menunjukan bahwa pengetahuan pemilik akan pemeliharaan peralatan DAMIU yang kurang terhadap kontaminasi bakteriologis (MPN E.Coli) terkontaminasi sebanyak 4 DAMIU (100\%) dan pada pengetahuan pemilik pada pemeliharaan peralatan DAMIU yang tinggi terhadap kontaminasi bakteriologis (MPN E.Coli) yang 
tidak terkontaminasi sebanyak 17 DAMIU $(68,0 \%)$.

Berdasarkan uji statistik diperoleh nilai $p=0,044$ dimana menggunakan nilai $\alpha$ 0,05 diperoloeh kesimpulan terdapat hubungan yang bermakna antara pengetahuan pemilik pada pemeliharaan peralatan DAMIU dengan Kontaminasi Bakteriologis (MPN E.Coli) air minum isi ulang di wilayah Kecamatan Johar Baru Jakarta Pusat tahun 2020.

Pengetahuan merupakan hasil dari tahu, dan ini akan terjadi setelah seseorang telah melakukan atau memfungsikan alat indera nya terhadap objek tertentu. Pengetahuan yang didapat oleh manusia sebagian besar berasal dari mata serta telinga. (6)

Berdasarkan hasil penelitian hubungan antara pengetahuan pemilik pada pemeliharaan peralatan dengan kualitas bakteriologis masih didapatkan hasil $8(32,0 \%)$ depot air minum isi ulang yang berpengetahuan tinggi namun terkontaminasi. Menurut penulis hal ini mungkin terjadi disebabkan karena pemilik tidak menerapkan apa yang sudah mereka ketahui terhadap pemeliharaan peralatan untuk menjaga kualitas air minumnya, selain itu belum adanya komiment antara pemilik depot air minum dengan puskesmas untuk sama-sama menjaga pemeliharaan peralatan pada depot air minum isi ulang.
Dari hasil wawancara dan observasi diperoleh bahwa pemilik depot air minum isi ulang menurut garis besar sudah mengetahui tentang pemeliharaan peralatan depot air minum dikarenakan para petugas puskesmas akan menjadwalkan pembinaan terhadap depot air minum isi ulang 2 kali dalam setahun. Namun memang masih kurangnya pengetahuan pemilik tentang kegunaan serta perawatan dari lampu Ultraviolet. Petugas juga memberikan pembinaan langsung kepada pemilik depot air minum isi ulang yang hasil pemeriksaannya tidak memenuhi syarat untuk dilakukan perbaikan dan menjaga kebersihan depot air minum isi ulang. Tetapi masih terdapat depot air minum isi ulang yang kualitas air minumnya tetap tidak memenuhi syarat.

Hubungan Kelengkapan Administrasi Depot Air Minum Isi Ulang Dengan Kualitas Bakteriologis (MPN E.Coli)

Berdasarkan hasil pengolahan data yang telah dilakukan diperoleh bahwa pada kelengkapan administrasi DAMIU yang tidak memenuhi syarat terhadap kontaminasi bakteriologis (MPN E.Coli) terkontaminasi sebanyak 7 DAMIU (100\%) dan pada kelengkapan administrasi DAMIU yang memenuhi syarat terhadap kontaminasi bakteriologis (MPN E.Coli) yang tidak terkontaminasi sebanyak 17 DAMIU (77,3\%).

Berdasarkan uji statistik di peroleh nilai $p=0,001$ selanjutnya akan disimpulkan terdapat hubungan bermakna antara 
kelengkapan administrasi DAMIU dengan Kontaminasi Bakteriologis di Wilayah Kecamatan Johar Baru Jakarta Pusat Tahun 2020.

Dari hasil analisis diperoleh nilai Odds Ratio $(O R)=4,400$ artinya bahwa kelengkapan administrasi DAMIU yang tidak memenuhi syarat mempunyai peluang atau kesempatan untuk Terkontaminasi Bakteriologis (MPN E.Coli) 4,400 kali lebih besar dibandingkan memenuhi syarat dan Tidak Terkontaminasi Bakteriologis (MPN E.Coli).

Menurut Kepmenperindag No. 651 Tahun 2004 menyebutkan bahwa depot air minum diwajibkan mempunyai surat jaminan pasok air baku dari PDAM atau perusahaan mempunyai izin pengambilan air dari instansi yang berwenang dan mempunyai laporan hasil uji air minum yang dihasilkan dari laboratorium pemeriksaan kualitas air yang ditunjuk Pemerintah Kabupaten atau Kota atau yang terakreditasi. (4)

Berdasarkan hasil penelitian disimpilkan ada hubungan antara kelengkapan administrasi dengan kualitas bakteriologis masih didapatkan hasil 5 (22,7\%) depot air minum isi ulang yang memenuhi syarat namun terkontaminasi. Menurut penulis hal ini mungkin terjadi karena terdapat kontaminasi pada proses pengangkutan air baku, mulai dari mobil pengangkut air baku hingga pada saat proses penyaluran air baku.

Dari hasil wawancara dan observasi didapatkan hasil masih terdapat pemilik depot air minum isi ulang yang kurang melakukan pengawasan terhadap perusahaan pemasok air baku. Sehingga air baku yang dikirim oleh perusahaan pemasok air baku tidak dapat di jamin kualitas air minumnya oleh pemilik depot air minum isi ulang, apakah memenuhi syarat atau tidak memenuhi syarat. perihal ini bagi penulis dapat jadi salah satu aspek yang bisa mempengaruhi kualitas atau mutu air minum pada depot air minum isi ulang sebab tidak terdapat fakta bahwa air baku yang diolah mempunyai kualitas yang baik. Selain itu beberapa depot air minum isi ulang tidak menyimpan juga tidak memasang hasil pemeriksaan air minum yang sudah dilakukan oleh puskesmas sehingga pembeli tidak tahu bagaimana kualitas dari air minum isi ulang yang mereka beli.

\section{KESIMPULAN}

Berdasarkan hasil penelitian didapatkan dalam penelitian ini, maka kesimpulan yang dapat diambil adalah sebagai berikut :

1. Terdapat hasil Laboratorium pada Depot Air Minum Isi Ulang di wilayah Kecamatan Johar Baru Jakarta Pusat tahun 2020 dari 29 DAMIU di dapatkan hasil bahwa depot air minum isi ulang yang terkontaminasi bakteriologis (MPN E.Coli) sebanyak 12 DAMIU (41,4\%). (75,9\%).

2. Pada penelitian diperoleh bahwa terdapat korelasi antara masa pemakaian lampu UV, pengetahuan pemilik pada 
pemeliharaan peralatan, dan kelengkapan administrasi dengan Kontaminasi Bakteriologis (MPN E.Coli) Air Minum Isi Ulang di Wilayah Kecamatan Johar Baru Jakarta Pusat Tahun 2020.

\section{Ucapan Terimakasih :}

Ucapan terimakasih penulis kepada

1. Prof. Dr. drg. Tri Budi Wahyuni Raharjo, M.S, selaku Rektor Universitas Respati Indonesia;

2. Zainal Abidin, M.Sc selaku Dekan Fakultas IImu Kesehatan Universitas Respati Indonesia;

3. Sri Widodo, SE, M.Kes selaku Ketua Program Studi Kesehatan Masyarakat Universitas Respati Indonesia

4. Dr. Yeny Sulistyowati, SKM., M.Si.Med selaku Kepala LPPM beserta staf

5. Kepala dan staf Puskesmas Kecamatan Johar Baru

6. Segenap pemilik Depot Air Minum Isi Ulang di Wilayah Kecamatan Johar Baru

\section{DAFTAR PUSTAKA}

1 Kemenkes. Sanitasi Total Berbasis Masyarakat. Jakarta: Kementrian Kesehatan RI; 2014.

2 Penelitian B, Pengembangan Dan. Riset Kesehatan Dasar. 2013;

3 Marpaung MDO, Marsono BD. Uji kualitas air minum isi ulang di kecamatan Sukolilo Surabaya ditinjau dari perilaku dan pemeliharaan alat. J

Tek ITS. 2013;2(2):D166-70.

4 Kepmenperindag_Nomor_651_Tahun _2004. 2004.

5

Navratinova S. Hubungan Kualitas Lampu Ultraviolet (Uv) Dengan Kualitas Bakteriologis Air Minum Hasil Produksi Depot Air Minum Isi Ulang (DAMIU)(Studi Di Kecamatan Pontianak Selatan Kota Pontianak). J e print undip. 2018;

Notoatmodjo S. Kesehatan Masyarakat IImu dan Seni [Internet]. Rineka Cipta; 2011. Available from: https://kesmasid.com/buku-kesehatan-masyarakatilmu-seni-ed-revisi-2011-soekidjonotoatmodjo/ 